\title{
Middle School Students' Devotion to Democratic Values
}

\author{
Hilmi SÜNGÜ*
}

Öz

Democracy as a political system aims to improve individuals' welfare and is considered as a desirable regime for that reason. Even if it is defined in different ways pointing out various aspects based on time and cultural background of societies, it has some common values shared by every person like equality, respecting life, justice, freedom, honesty, the search for goodness, cooperation, self-esteem, tolerance, sensibility, responsibility, acceptance of difference and so forth. This study aimed to determine the devotion level of Turkish 8th grade students to democratic values. The sample of the study comprised of 448 8th graders attending to middle schools located in Yozgat. In order to collect the necessary data Democratic Values Scale developed by İlgan et al. (2013) was used. According to the findings of the study, it was seen that Turkish 8th grade students adopted democratic values at a high level.

Keywords: Democracy, democratic values, middle school, student.

\section{Ortaokul Öğrencilerinin Demokratik Değerlere Bağlılık Düzeyleri}

$\ddot{O} z$

Demokrasi bir politik sistem olarak bireylerin refah düzeylerini geliştirmeyi amaçlar ve bu nedenle cazip bir yönetim şekli olarak kabul edilmektedir. Demokrasi toplumların kültürel özellikleri ve yaşanılan zamana göre farklı şekillerde tanımlansa da; eşitlik, yaşam hakkına saygı, adalet, özgürlük, dürüstlük, iyiliği arama, işbirliği, özsaygı, hoşgörü, duyarlılık, sorumluluk duygusu, farklılıkları kabul etme vb. gibi ortak değerleri barındırmaktadır. Bu çalışma 8. Sınıfa devam etmekte olan Türk öğrencilerin demokratik değerlere bağlllık düzeylerini belirlemeyi amaçlamaktadır. Araştırma örneklemi Yozgat'ta bulunan ortaokulların 8. sınıflarına devam etmekte olan 448 öğrenciden oluşmaktadır. Gerekli verilerin toplanması için İlgan vd. (2013) tarafından geliştirilmiş olan Demokratik Değerler Ölçeği'nden yararlanılmıştır. Araştırma bulgularına göre 8. sınıf öğrencilerinin demokratik değerleri yüksek bir düzeyde benimsedikleri belirlenmiştir.

Anahtar Kelimeler : Demokrasi, demokratik değerler, ortaokul, öğrenci .

\footnotetext{
* Assistant Professor, Bozok University Faculty of Education, Department of Educational Sciences, hilmisungu@hotmail.com
} 


\section{INTRODUCTION}

Democracy is a concept on which every individual has different perceptions. With the effects of globalization people's views on social life and personal rights and common values have changed. Besides, it is not easy to make a common definition of democracy as the perceptions differed due to cultural, social and personal aspects. Thus, it is not easy to measure democratic values that people have and share. However, there is general agreement that the classical definition of democracy is made up of four key components: (1) it is a political system where citizens have right to choose their government through free and fair elections; (2) citizens participate actively in politics and civic life; (3) the rights of citizens are protected; (4) citizens are governed by rules of law and procedures and all citizens are equal before the law (Abrahams and Smith, 2011).

In all the key components mentioned above, it might be noticed that citizen or individual is of the essential elements. Thus, education is one of the useful ways of improving democratic values. Values like respecting diversity, respecting human rights, tolerance and so forth are supported and taught in national curriculum through courses like social sciences and civic education. Schools are the places where the foundations of democratic societies established and prepare youth for their future roles as democratic citizens in a democratic society. For Dewey, building a democratic society means creating a way of living together, of learning to cooperate, of appreciating and learning from diversity and of coming to support one another for the good of the whole (Cohen et al., 2010).

Therefore, the study aimed to find out about the democratic values that Turkish middle school students had. The reason for selecting the $8^{\text {th }}$ graders was due to the assumption that they know the concept better and were more aware of democratic values compared to the lower grade students since the $8^{\text {th }}$ grade students took a must course on citizenship and democracy education (citizenship and democracy education was a must course until 20142015 academic year for the $8^{\text {th }}$ grade students. Starting from 2015-2016 academic year a new curriculum has been started and the course has started to be given for the $4^{\text {th }}$ graders). Seeing the importance of democratic values, this study tried to find the answers to the following questions:

1. What level are the middle school students adopted democratic values?

2. Is there a significant relationship between the democratic values of the students and their demographic variables like gender, the place where the students lived, parents' educational background, number of the children in the family and parents' profession?

\subsection{Theoretical Framework}

Democracy is a word which has etymologically Greek and the word "demos" was used to refer "people and "krasia" was used to mean sovereignty (Şaylan, 1998, 13). The regimes based on popular sovereignty are called democratic regimes. It remains as an ideal or desirable regime since it is based on the principle of individuals' well being and good governance (Slev, 2014). In today's world democracy has a wider meaning compared to the past. Now, as a concept, it includes individual liberties, self improvement and the provision of necessary means to achieve these (Ural, 2013).

In spite of the diversity in the meaning of democracy as a concept depending on time and cultural background of societies, it has common elements which have not changed in time and shared by everyone. Kincal and Işık (2003) specified the values mentioned in the related studies as; equality, respecting life, justice, freedom, honesty, the search for goodness, cooperation, self-esteem, tolerance, sensibility, responsibility, acceptance of difference, safety, peace, development, perfection, and effectiveness. Ulusoy (2007) indicated that respect for 
humanely values (human rights, respecting equality, respecting diversity, respecting freedom of conscience, avoiding from deception, avoiding from discrimination), behaving benevolently, integrating between self interest and social responsibilities, honesty, considering ethical principles, solving individual conflicts in a peaceful way are of the basic values which students should possess,. Sarı (2007) restated that democratic values might be grouped under 20 basic items as; equality, independence, freedom, self respect, respect for human dignity, friendship, benevolence, cooperation, privacy, honesty, integrity, responsibility, justice, righteousness, diversity, tolerance, respect for environment, supremacy of law, finding peaceful solutions for conflicts and respect for international human rights.

Knowing about the above mentioned democratic values does not mean that these values are performed adequately by every individual in the society during daily activities. People's being aware of the values is not sufficient enough to build a democratic atmosphere in the society. The values should be internalized and they should be performed in daily life and sustainability of them should be provided (Güven, 2007). Schools are the essential places where democratic ideals are instilled. Teachers' attitudes and maintaining a democratic atmosphere in the classrooms play important role in teaching democracy at schools. Teachers' might manage this challenging task by supporting the students' decisions, empowering them to explore issues, to discuss and formulate their opinions, trusting them to organize events and so forth (Subba, 2014). Kepenekçi (2003) pointed out the importance of the teacher's role and his/her guidance in the students' gaining democratic values at school and stressed that these values should be a part of school life. Moreover, it could be stated that not only the schools, but also family, media and other institutions contribute to this process as well (Subba, 2014). Aggarwal (2005) stated that teaching students democratic values has three phases: (1) Conveying the meaning of democratic values; (2)
Enabling the students to incorporate these values in their daily routine (3) Providing a democratic school atmosphere which introduces radical changes in educational processes.

In the related literature, we see numerous studies dealing with democracy perceptions of differing age groups from various parts of the world. To illustrate, Abrahams and Smith (2011) tried to find out what democracy meant for ordinary South African citizens and how democracy improved their lives. It was seen that the respondents understood and found value in democracy in its classical sense; they define democracy by the socioeconomic outcomes which it delivers. In the study carried out by Daher (2012), the issues related to democracy in math classes were concerned. The participants emphasized that instructors should not exert their power to stop the flow of students' actions in the mathematics classroom, because this would trouble them and make them lose control of their actions. The study by Hahn (2003) yielded information about the development of democratic attitudes the $9^{\text {th }}$ grade students in the USA. As a result, the students rated free expression and free elections as most important for democracy, they were less sure about the importance of peaceful protests and they were above the international average in their support of rights for both women and immigrants.

As for the studies conducted in Turkey, in the study by Çetinkaya and Kincal (2015) it was aimed to determine education efficacy presented the gifted children to increase their awareness for love, tolerance and democracy. At the end of the study it was found that the awareness training was effective and seen that the answers which the students gave to the semistructured interview form focused on being a person who is respectful to individual rights, respectful, prudent, libertarian, showing patience. Demir and Bedir (2013) asked teachers to evaluate their colleagues' instructional processes in terms of democracy. Majority of teachers who participated in the study were 
evaluated as individuals who internalized democratic education and management, liked their jobs, had mature thinking skills, who were energetic, tolerant, unbiased, and respectful. İlgan et al. (2013) analyzed the middle school students' democratic values and the results showed that middle school students adopted democratic values in high level. Akın and Özdemir (2009) carried a study analyzing the democratic values of the teacher candidates in Turkey under three subscales as; right to education, freedom and solidarity. The results indicated that the teacher candidates' democratic values were quite high. Doğanay and Sarı (2004) examined 8th grade students' devotion level to democratic values and found out that devotion level of students to democratic values was found to be higher than their teachers' estimated.

\section{METHODOLOGY}

The aim of this study was to describe the $8^{\text {th }}$ graders level of devotion to democratic values. The study was conducted using the survey method and it was limited with the $8^{\text {th }}$ grade students' who took civic education course and attended to the schools located in Yozgat. This city was selected as a research site because of its accessibility to the researcher.

\subsection{Target Population}

Target population of the study comprised of the $8^{\text {th }}$ grade students attending to the randomly selected middle schools located in the city center of Yozgat and to the middle schools located in randomly selected towns of Yozgat during 2014-2015 academic year. About 8.000 $8^{\text {th }}$ grade students were studying at schools in Yozgat, the towns and the countryside of Yozgat. Schools in the scope of the study were selected randomly and the paper surveys were distributed to the students who agreed to participate in the study. As a consequence, Totally 800 students from eight selected schools were administrated the surveys. 523 of the distributed surveys were responded by the participants and 448 of them which were completely and accurately responded were considered to be appropriate for analysis. The return rate of the surveys was $65.37 \%$. See Table 1 for the detailed information concerning the participants.

Table 1. Personal details about the participant students

\begin{tabular}{llcc}
\hline Variable & Level & N & \% \\
\hline \multirow{2}{*}{ Gender } & Boy & 202 & 54.9 \\
& Girl & 246 & 45.1 \\
\hline \multirow{2}{*}{ Place where the student live } & City center & 254 & 56.7 \\
& Town/village & 194 & 43.3 \\
\hline \multirow{3}{*}{ Mother's educational background } & Elementary or lower & 231 & 51.6 \\
& Middle School & 125 & 27.9 \\
& High School or above & 92 & 20.5 \\
\hline \multirow{3}{*}{ Father's educational background } & Elementary or lower & 139 & 31.0 \\
& Middle School & 103 & 23.0 \\
& High School or above & 206 & 46.0 \\
\hline \multirow{3}{*}{ Number of the children in the } & One or two children & 80 & 17.8 \\
& Three children & 142 & 31.7 \\
& Four children & 115 & 25.7 \\
\multirow{2}{*}{ Mother's profession } & Five or more & 111 & 24.8 \\
\hline \multirow{2}{*}{ Father's profession } & Housewife & 404 & 90.2 \\
& Other & 44 & 9.8 \\
\hline
\end{tabular}




\subsection{Instruments and Procedures}

In order to measure the students' democratic values, the "Democratic Values Scale" developed by İgan et al. (2013) was used by the researcher. The scale was a five-point-Likert scale and had the responses like (1) Completely disagree; (2) Disagree; (3) Neutral; (4) Agree; and (5) Completely agree. The scale had six subscales (see Table 2) and 24 statements. Exploratory Factor Analysis showed that the scale explained $56.82 \%$ of total variance; internal consistency coefficient alpha was .906. Factor loadings ranged from. 325 to .658 .

Table 2. Statistics related to the subscales of Democratic Values Scale

\begin{tabular}{lccc}
\hline \multicolumn{1}{c}{ Subscales } & $\begin{array}{c}\text { Number } \\
\text { of items }\end{array}$ & $\begin{array}{c}\text { Explained vari- } \\
\text { ance } \%\end{array}$ & $\begin{array}{c}\text { Communalities } \\
\text { range }\end{array}$ \\
\hline 1. Respect for equality and diversity & 5 & 14.41 & $.345-.549$ \\
2. Respect for other people's rights & 5 & 13.60 & $.453-.589$ \\
3. Tolerance and diversity & 4 & 12.65 & $.474-.658$ \\
4. Freedom of other people & 3 & 8.65 & $.476-.628$ \\
5. Respect for other people's diversity & 4 & 4.40 & $.325-.634$ \\
6. Sensitivity to diversity & 3 & 3.11 & $.475-.539$ \\
\hline & \multicolumn{3}{c}{$\begin{array}{l}\text { Reliability coefficient } \\
\text { Total Variance Explained: 56.82 }\end{array}$} \\
\hline
\end{tabular}

The data were analyzed by SPSS (Version 20). Percentages and frequencies were used to analyze demographic variables. To describe students' attitudes toward addicts, descriptive statistics such as mean and standard deviation and to compare participants' responses in terms of demographic variables, independent samples t-test, One-Way-ANOVA and Mann Whitney $\mathrm{U}$ test were used.

\section{FINDING}

In this section, the findings regarding the students' devotion level of democratic values and comparisons showing if personal variables have any relations and caused any significant differences concerning their democratic values were given below.

\subsection{The Findings related to Respect for Equali- ty and Diversity Subscale}

The findings of the study showed that students "strongly agreed" to the statements given in the subscale. For the descriptives related to the "Respect for Equality and Diversity Subscale" see Table 3.

Table 3. Respect for equality and diversity

\begin{tabular}{|c|c|c|c|}
\hline Item & $\mathbf{N}$ & $\mathbf{X}^{-}$ & Sd \\
\hline $\begin{array}{l}\text { 1. I think respecting the people who are different } \\
\text { from me makes the classroom atmosphere more } \\
\text { democratic. }\end{array}$ & 448 & 4.35 & 1.02 \\
\hline $\begin{array}{l}\text { 2. I respect my friends no matter what their } \\
\text { language, religion, ethnic identity are. }\end{array}$ & 448 & 4.58 & .778 \\
\hline $\begin{array}{l}\text { 3. It is usual if my friends speak with their local } \\
\text { accent. }\end{array}$ & 448 & 4.35 & .992 \\
\hline $\begin{array}{l}\text { 4. I do not discriminate between the rich and } \\
\text { poor friends. }\end{array}$ & 448 & 4.66 & .565 \\
\hline $\begin{array}{l}\text { 5. Girls and boys should have equal rights at } \\
\text { home and in social life. }\end{array}$ & 448 & 4.49 & 1.01 \\
\hline Total & 448 & 4.49 & .602 \\
\hline
\end{tabular}


Considering the average scores; the students' devotion to democratic values in the Respect for Equality and Diversity Subscale were found to be at a high level $\left(X^{-}=4.49\right)$. Out of five given statements in the subscale the most favorable responses were given to "I do not discriminate between the rich and poor friends." $\left(X^{-}=4.66\right)$; while the least two favorable statements in the subscale were "I think respecting the people who are different from me makes the classroom atmosphere more democratic." $\left(X^{-}=4.35\right)$ and "It is usual if my friends speak with their local accent." $\left(\mathrm{X}^{-}=4.35\right)$.

\subsection{The Findings related to Respect for Other People's Rights Subscale}

The findings of the study showed that students "strongly agreed" to the statements given in the subscale. For the descriptives related to the "Respect for Other People's Rights Subscale" see Table 4 .

Table 4. Respect for other people's rights

\begin{tabular}{lccc}
\hline \multicolumn{1}{c}{ Item } & $\mathbf{N}$ & $\mathbf{X}^{-}$ & Sd \\
\hline $\begin{array}{l}\text { 6. I appreciate the others' views and opinions. } \\
\begin{array}{l}\text { 7. I am careful and behave respectfully while } \\
\text { criticizing others. }\end{array}\end{array}$ & 448 & 4.49 & .851 \\
$\begin{array}{l}\text { 8. I listen carefully what my friends said and } \\
\text { wait until they finish their words if Ineed to } \\
\text { object. }\end{array}$ & 448 & 4.46 & .787 \\
$\begin{array}{l}\text { 9. I behave in a way how I like the others } \\
\text { behave to me. }\end{array}$ & 448 & 4.39 & .895 \\
$\begin{array}{l}\text { 10. I might not support my friends' views, } \\
\text { still I respect them. }\end{array}$ & 448 & 4.35 & .957 \\
\hline Total & 448 & 4.41 & .913 \\
\hline
\end{tabular}

Considering the average scores; the students' devotion to democratic values in the Respect for Other People's Rights Subscale were found to be at a high level $\left(X^{-}=4.42\right)$. Out of five given statements in the subscale the most favorable responses were given to "I appreciate the others' views and opinions." ( $\left.\mathrm{X}^{-}=4.49\right)$; while the least favorable statement in the subscale was "I behave in a way how I like the others behave to me." $\left(X^{-}=4.35\right)$.

\subsection{The Findings related to Tolerance and Diversity Subscale}

The findings of the study showed that students "agreed" to the statements given in the subscale. For the descriptives related to the "Tolerance and Diversity Subscale" see Table 5.

Table 5. Tolerance and diversity

\begin{tabular}{llcc}
\hline \multicolumn{1}{c}{ Item } & $\mathbf{N}$ & $\mathbf{X}^{-}$ & Sd \\
\hline $\begin{array}{l}\text { 11. I can make friend with a person who } \\
\text { believe in some other religion. }\end{array}$ & 448 & 3.81 & 1.35 \\
$\begin{array}{l}\text { 12. I am not disturbed if a different lan- } \\
\text { guage is spoken nearby. }\end{array}$ & 448 & 3.87 & 1.35 \\
$\begin{array}{l}\text { 13. I can make friends with people who } \\
\text { have different political views. }\end{array}$ & 448 & 4.20 & 1.10 \\
$\begin{array}{l}\text { 14. I can communicate and make friends } \\
\text { with people who has different characteris- } \\
\text { tics from me. }\end{array}$ & 448 & 4.46 & .863 \\
\hline Total & 448 & 4.08 & .825 \\
\hline
\end{tabular}




\subsection{The Findings related to Freedom of Other} People Subscale

The findings of the study showed that students

"strongly agreed" to the statements given in the subscale. For the descriptives related to the "Freedom of Other People" see Table 6.

Table 6. Freedom of other people

\begin{tabular}{lccc}
\hline \multicolumn{1}{c}{ Item } & $\mathbf{N}$ & $\mathbf{X}^{-}$ & Sd \\
\hline $\begin{array}{l}\text { 15. People who are from different regions } \\
\text { have right to settle down in my hometown. }\end{array}$ & 448 & 4.37 & 1.01 \\
$\begin{array}{l}\text { 16. I can make friends with my classmates } \\
\text { no matter where they are from. }\end{array}$ & 448 & 4.46 & .935 \\
$\begin{array}{l}\text { 17. Every person should have the right to } \\
\text { explain his views and emotions appropriate- }\end{array}$ & 448 & 4.58 & .839 \\
$\begin{array}{l}\text { ly. } \\
\text { Total }\end{array}$ & 448 & 4.47 & .750 \\
\hline
\end{tabular}

Considering the average scores; the students' devotion to democratic values in the Freedom of Other People Subscale were found to be at a high level $\left(X^{-}=4.47\right)$. Out of three given statements in the subscale the most favorable responses were given to "Every person should have the right to explain his views and emotions appropriately." ( $\left.X^{-}=4.58\right)$; while the least favorable statement in the subscale was "People who are from different regions have right to settle down in my hometown." ( $\left.X^{-}=4.37\right)$.

\subsection{The Findings related to Respect for Other People's Diversity Subscale}

The findings of the study showed that students "strongly agreed" to the statements given in the subscale. For the descriptives related to the "Respect for Other People's Diversity" see Table 7.

Table 7. Respect for other people's diversity

\begin{tabular}{lccc}
\hline \multicolumn{1}{c}{ Item } & $\mathbf{N}$ & $\mathbf{X}^{-}$ & Sd \\
\hline $\begin{array}{l}\text { 18. I think every person has different charac- } \\
\text { teristics. }\end{array}$ & 448 & 4.25 & 1.14 \\
$\begin{array}{l}\text { 19. I think it is usual that every person has } \\
\text { different point of view. }\end{array}$ & 448 & 4.46 & .945 \\
$\begin{array}{l}\text { 20. I think people might have different solu- } \\
\text { tions for the same problems. }\end{array}$ & 448 & 4.46 & .908 \\
$\begin{array}{l}\text { 21. People who are mentally or physically } \\
\text { handicapped should have the equal rights } \\
\text { with me. }\end{array}$ & 448 & 4.44 & 1.04 \\
\hline Total & 448 & 4.40 & .741 \\
\hline
\end{tabular}

Considering the average scores; the students' devotion to democratic values in the Respect for Other People's Diversity Subscale were found to be at a high level $\left(X^{-}=4.40\right)$. Out of four given statements in the subscale the most favorable responses were given to "I think it is usual that every person has different point of view." $\left(X^{-}=4.46\right)$ and "I think people might have different solutions for the same problems." $\left(X^{-}=4.46\right)$; while the least favorable 
statement in the subscale was "I think every person has different characteristics." ( $\left.X^{-}=4.25\right)$.

\subsection{The Findings related to Sensitivity to $\mathrm{Di}$ -} versity Subscale
The findings of the study showed that students "strongly agreed" to the statements given in the subscale. For the descriptives related to the "Sensitivity to Diversity" see Table 8.

Table 8. Sensitivity to diversity

\begin{tabular}{llcc}
\hline \multicolumn{1}{c}{ Item } & $\mathbf{N}$ & $\mathbf{X}^{-}$ & Sd \\
\hline $\begin{array}{l}\text { 22. I think my friends' personal diversities } \\
\text { are kind of richness. }\end{array}$ & 448 & 4.11 & 1.19 \\
$\begin{array}{l}\text { 23. I try my friends to be understanding to } \\
\text { the ones who have learning disabilities. }\end{array}$ & 448 & 4.40 & .950 \\
$\begin{array}{l}\text { 24. I try to defend and demand justice for } \\
\text { my friends who are discriminated or biased. }\end{array}$ & 448 & 4.41 & .983 \\
\hline Total & 448 & 4.31 & .795 \\
\hline
\end{tabular}

Considering the average scores; the students' devotion to democratic values in the Sensitivity to Diversity Subscale were found to be at a high level $\left(X^{-}=4.31\right)$. Out of three given statements in the subscale the most favorable responses were given to "I try to defend and demand justice for my friends who are discriminated or biased." ( $\left.X^{-}=4.41\right)$; while the least favorable statement in the subscale was "I think my friends' personal diversities are kind of richness." $\left(X^{-}=4.11\right)$.

\subsection{Comparing Students' Democratic Values} According to Their Demographic Characteristics

Within the scope of the study demographic characteristics of the participant students were taken into the consideration to find out if their devotion to democratic values had any relationship with their demographic variables or not. As the result of the analysis, it was found out that there were meaningful differences between the students democratic values based on their gender and the place where they lived. As a result of the analysis, it was seen that there were significant differences between male and female students' democratic values in all of the subscales. According to the findings of the study female students' devotion to democratic values was seen to be higher than male students. Similarly, it was found that there were significant differences between the students' democratic values based on the place where they lived as in our out of the city center. In all of the subscales significant differences were found between the students' devotion to democratic values based on the place where they lived. It might be stated that the students who lived in towns or villages (who lived outside city center) adopted democratic values more and had higher scores from the scale compared to the students living in the city center.

On the other hand, the results of the analysis showed that no statistically meaningful differences were found between the students' democratic values based on the variables like their mothers' and fathers' educational background, mothers' and fathers' profession, and the number of the children in the family.

\section{DISCUSSION}

The study aimed to determine Turkish middle school students' levels of devotion to democratic values. The results of the study indicated that 
students strongly agreed to the statements included in the five subscales as respect for equality and diversity, respect for other people's rights, freedom of other people, respect for other people's diversity and sensitivity to diversity. Students' scores were noticed to be comparatively lower in a subscale (tolerance and diversity) and they were seen to just agree to the statements in the mentioned subscale. The findings of the study might be considered to be consistent with the numerous studies carried out in Turkey on this issue (e.g., Akın and Özdemir, 2009; Çetinkaya and Kincal, 2015; Doğanay and Sarı, 2004; Güven, 2007; İlgan et al., 2013; Topkaya and Yavuz, 2010; Uğurlu, 2014; Yüksel et al., 2013). In all these above mentioned studies, democratic values were seen to be high even if the sample population of the studies had diverse age groups or included people from differing locations from Turkey. When we consider the studies with the similar samples in terms of age group; Doğanay and Sarı (2004); İlgan et al. (2013), Sar1 et al. (2008) conducted their studies on elementary school students and determined that Turkish elementary students adopted democratic values at high levels. In the existing study, students' scores of devotion to these values were seen to be a bit higher than the mentioned studies. It could be asserted that students' devotion to democratic values at such a higher rate is somewhat positive situation even if the sample looks small. The reason might be because of the cultural background of the setting. Living in a small city which is not a cosmopolitan city and sharing similar attitudes, values, goals and practices might help to make people more tolerant towards the others.

Moreover, in the study it was pointed out personal variables such as gender and the place where students lived influenced the students views. That is, female students and the students living in towns or villages adopted democratic values better than the others. It might be said based on the findings of the study that Turkish elementary school students' levels of devotion to democratic values were high in general. But it must be highlighted that girls and students who lived in rural areas adopted democratic values higher than boys and the ones living in city center. The reasons which caused the difference might be because of the girls' being more tolerant, friendly and considerate in their social relationships. Additionally, it could be claimed that living in bigger settlements which composed of the people with differing political, cultural, economical backgrounds somewhat negatively affected the students' values. Therefore, students who lived in smaller regions had resembling views of life and this fact might make them more sympathetic and mindful of democratic values. In the previous studies done by Akın and Özdemir (2009), Güven (2007), Sarı et al. (2008), Yüksel et al. (2013) found out that there were significant differences between the students' democratic values based on gender. On the other hand, there are some studies which stated students' gender was not considered to be a significant variable which caused significant differences between the students' democratic values (e.g., Çetinkaya and Kincal, 2015; İlgan et al., 2013; Topkaya and Yavuz, 2011). In the findings of the similar studies, even if it was not at a statistically significant level, the girls were seen to be more devoted to democratic values compared to the boys. Thus, it might be stressed that the findings seemed similar to the results obtained from the studies of Illgan et al. (2013) and Topkaya and Yavuz (2011). Furthermore, in the study carried out by Yüksel et al. (2013), it was restated that being in different cities made significant differences between the students' democratic values. So it might be claimed that location where people lived could sometimes be a significant factor influencing their democratic perceptions due to differing socio-cultural atmospheres of cities.

What is more, in the study it was indicated that the personal variables like father's and mother's educational backgrounds, their profession and the number of the children in the family 
did not make any significant differences on the students' devotion to democratic values. There are similar findings from some other studies on the issue. For instance, Yüksel et al. (2013) affirmed that students' scores related to their responses to the scale did not significantly differ from each others based on the number of the people in their families. Correspondingly, İlgan et al. (2013) stressed depending on their findings that variables such as students' parents' education level, parents' job, number of brothers and sisters did not affect democratic values of middle school students. However, Çetinkaya and Kincal (2015) emphasized considering the result of their research that students' parents' educational levels and their professions had influence on their democratic values and made significant differences on their devotion to democracy.

\subsection{Implications and Recommendations for Further Research}

It was found out in the study that the students participated to the study showed a devotion rate to democratic values at a high level. Based on these results, factors influence students' devotion to democratic values including gender and the place where the students lived. Meanwhile the limitations of the study had better be emphasized in this point. Firstly, the data was obtained from a particular city in Turkey and limited to the students' living there. Therefore it is not a nationwide study, future studies might be carried out on a larger national scale and qualitative studies might be designed to better understand students' democratic values and related factors.

Moreover, the study is a descriptive one and the results just displayed the existing situation related to the issue. In the further studies, the new curriculum which has been started for the $4^{\text {th }}$ graders regarding human rights, citizenship and democracy could be taken into consideration; an evaluation of the application of the new curriculum in terms of strengths and weaknesses could be made together with indicating the gains of the students from the course.

\section{References}

Abrahams, M.\&Smith, J. (2011). A Study of Perceptions around Democracy in Six Communities in the Umgungundlovu District Municipality, KwaZulu-Natal. PACSA: 2010 Democracy Perception Barometer.

Aggarwal, J.C. (2005). Teaching and Education in a Developing Society (4th Edition). New Delhi: Viking Publishing House

Akın, U.\&Özdemir, M. (2009). An examination of teacher candidates' democratic vaşues in terms of various variables: The case of faculty of educational sciences. Journal of Faculty of Educational Sciences, 42( 2), 183-198.

Cohen, J., Pickeral, T.\&Levine, P. (2010). The foundation for democracy: Promoting social, emotional, ethical, cognitive skills and dispositions in K-12 schools. Interamerican Journal of Education for Democracy, 3(1), 74-94.

Çetinkaya, Ç.\&Kincal, R.Y. (2015). Democracy education of gifted and talented children. Journal of Gifted Education Research, 2015, 3(1), 1-22. 
Daher, W. (2012). Student teachers' perceptions of democracy in the mathematics classroom: Freedom, equality and dialogue. Pythagoras, 33(2), Art. \#158.

Demir, S.\&Bedir, G. (2013). An assessment of instructional practices in terms of democratic participation, freedom and autonomy. Journal of Educational and Instructional Studies in the World, 3(1), $32-43$.

Doğanay, A.\&Sarı, M. (2004). Elementary school students' devotion level to democratic values and comparison of the effect of overt and hidden curriculum on gaining democratic values in terms of students' and teachers opinions. Kuram ve Uygulamada Eğitim Yönetimi. 39, 356-383.

Güven, A. (2007). Studying democratic attitude of the students in history education in terms of individual variables. Kazım Karabekir Eğitim Fakültesi Dergisi, 15, 36-61.

Hahn, C.L. (2003). Democratic values and citizen action: A view from U.S. 9th graders. International Journal of Educational Research, 39, 633-642.

İlgan, A., Karayiğit, D.\&Çetin, B. (2013). Examining democratic values of middle school students in terms of some variables. CBÜ Sosyal Bilimler Dergisi, 11(2), 97-118.

Kepenekçi, Y. (2003). Demokratik okul [Democratic school]. Eğitim Araştırmaları Dergisi [Eurasian Journal of Educational Research], 11, 44-53.

Kincal, R., \& Isik, H. (2003) Demokratik eğitim ve demokratik değerler [Democratic education and democratic values]. Eğitim Araştırmaları Dergisi [Eurasian Journal of Educational Research]. 11, 5458 .

Sarı, M. (2007). Demokratik değerlerin kazanımı sürecinde örtük program: Düşük ve yüksek "okul yaşam kalitesi"ne sahip iki ilköğretim okulunda nitel bir çalışma. Unpublished PhD. Dissertation. Adana: Çukurova Üniversitesi Sosyal Bilimler Enstitüsü.

Sarı, M., Sarı, S.\&Ötünç, M.S. (2008). An investigation of devotion to democratic values abd conflict resolution abilities: A case of elementary school students. Kuram ve Uygulamada Eğitim Bilimleri, 8(1), 183-192.

Slev, A.M. (2014). Perceptions of democracy and democratic principles among Romanian law students. Social-Behavioral Sciences, 1(73), 38-44.

Subba, D. (2014). Democratic values and democratic approach in teaching: a perspective. American Journal of Educational Research, 2, No. 12A, 37-40.

Şaylan, G. (1998). Demokrasi ve Demokrasi Düşüncesinin Gelişmesi [Democracy and the development of democratic thinking]. Ankara: TODAİE Masaüstü Yayıncıllk.

Topkaya, E.\&Yavuz, A. (2011). Democratic Values and Teacher Self-Efficacy Perceptions: A Case of PreService English Language Teachers in Turkey. Australian Journal of Teacher Education, 36(8), 3148.

Ulusoy, K. (2007). Lise Tarih Programlarında Yer Alan Geleneksel ve Demokratik Değerlere Yönelik Öğrenci Tutumlarının ve Görüşlerinin Çeşitli Değişkenler Açısından Değerlendirilmesi, Unpublished PhD. Dissertation, Gazi Üniversitesi Eğitim Bilimleri Enstitüsü, Ankara. 
Ural, A. (2013). An evaluation of the perception of democracy among university students through the use of metaphors. International Journal of Education and Research, 1(8), 1-14.

Yüksel, İ., Bağcı, Ş.\&Vatansever, E. (2013). Evaluation of affective learning outputs of primary school senior students: Democratic values. Adıyaman Üniversitesi Sosyal Bilimler Enstitüsü Dergisi, 6(12), 309-334. 